DOI: $10.15193 /$ zntj/2021/127/380

\author{
JOANNA MARKOWSKA, ELŻBIETA POLAK, ANNA DRABENT, \\ ALEKSANDRA ŻAK
}

\title{
KONOPIE SIEWNE CANNABIS SATIVA L. - ODMIANY, WŁAŚCIWOŚCI, ZASTOSOWANIE
}

\begin{abstract}
Streszczenie
Konopie siewne (Cannabis sativa L.) to starożytne rośliny uprawne o wielu zastosowaniach, pochodzące z Azji Środkowej. W pracy przedstawiono przegląd piśmiennictwa dotyczącego konopi, związków czynnych w nich zawartych, aktywności biologicznej, właściwości leczniczych oraz możliwości wykorzystania w medycynie i żywności. Szerokie zastosowanie w przemyśle spożywczym znajdują nasiona konopne, które są dobrym źródłem białka, błonnika, witaminy E, żelaza, wapnia, cynku, fosforu i magnezu. Za smak i zapach konopi odpowiedzialne są węglowodory terpenowe, głównie $\beta$-kariofilen i $\alpha$-humulen (seskwiterpeny) oraz monoterpen, mircen. Obecnie głównym obiektem zainteresowania przemysłu jest tłoczony z nasion olej bogaty w tokoferole, fitosterole, karotenoidy, polifenole i fosfolipidy. Olej konopny zawiera ponad $80 \%$ NNKT, w tym kwasy $\gamma$-linolenowy (GLA), linolowy i $\alpha$-linolenowy, przy optymalnym stosunku wielonienasyconych kwasów tłuszczowych omega- 6 do omega-3 w proporcji $3: 1$. Stosowanie oleju w technologii żywności jest ograniczone ze względu na intensywną jego barwę i smak. Inne związki aktywnie czynne identyfikowane w Cannabis sativa L. reprezentowane są przez kannabinoidy, dihydrostilbeny i spiroindany. Kannabinoidy charakteryzują się właściwościami przeciwzapalnymi, przeciwbakteryjnymi, przeciwbólowymi i przeciwdepresyjnymi. Produkty z nasion konopnych stanowią dodatki do herbat, kawy, wyrobów czekoladowych, napojów mlecznych, pieczywa i wyrobów cukierniczych, a także piwa, wina, miodu czy produktów dla sportowców. W artykule omówiono także wymagania prawne związane z możliwością zastosowań kannabinoidów w żywności oraz wprowadzaniem produktów spożywczych z ich udziałem do obrotu towarowego.
\end{abstract}

Słowa kluczowe: konopie siewne, kannabinoidy, THC, CBD, zastosowanie lecznicze i w żywności

\section{Wprowadzenie}

Od kilku lat obserwuje się wzrost zainteresowania żywieniowymi, użytkowymi i leczniczymi właściwościami konopi Cannabis sativa L. Rośliny te przez tysiące lat

Dr inż. J. Markowska, dr inż. E. Polak, mgr inż. A. Drabent, mgr inż. A. Żak, Zakład Technologii i Techniki Chtodnictwa, Instytut Biotechnologii Przemystu Rolno-Spożywczego im. Prof. W. DąbrowskiegoPaństwowy Instytut Badawczy, ul. Pitsudskiego 84,92-202 Łódź. Kontakt: joanna.markowska@ibprs.pl 
miały znaczącą pozycję w żywieniu i medycynie ludowej. Sprzedaż produktów konopnych w USA w 2017 roku wyniosła 820 milionów dolarów. Departament Rolnictwa Stanów Zjednoczonych w raporcie z 2019 r. przewiduje wzrost sprzedaży o 104 miliony dolarów do 2022 r. [37]. Prognozy wskazują, że rynek produktów certyfikowanych, pochodzących ze źródeł tzw. legalnych, do 2025 r. wzrośnie aż o 77 \% i osiągnie wartość 166 mld dolarów [18].

Pierwsze wzmianki o użytkowaniu konopi spotyka się w chińskim rękopisie pochodzącym z XXVIII w. p.n.e. Przypuszcza się, że konopie były najstarszymi roślinami włóknistymi uprawianymi przez Japończyków, Mongołów i Tatarów. Prawdopodobnie gatunek Cannabis pochodzi z Azji Centralnej, skąd rozprzestrzenił się na tereny Azji Wschodniej i Południowej oraz na zachód do Europy $[11,25]$. Obecnie konopie uprawiane są w ok. 30 krajach w Europie, Azji oraz Ameryce Północnej i Południowej [25]. Według danych Organizacji Narodów Zjednoczonych ogólnoświatowy areał upraw konopi szacuje się na ok. 70819 ha. Dane te nie obejmują jednak wszystkich krajów, w tym Kanady, która jest głównym producentem i eksporterem konopi. Całkowita wielkość upraw we wszystkich krajach europejskich wynosi ponad 28327 ha, co stanowi ok. dwóch trzecich światowej produkcji zgłoszonej przez ONZ. Większość jest skupiona we Francji, Holandii, na Litwie i w Rumunii. Inne kraje z aktywnymi producentami konopi i/lub rynkami konsumenckimi to: Australia, Nowa Zelandia, Indie, Japonia, Korea, Turcja, Egipt, Chile i Tajlandia [25]. Produkcja obejmuje zarówno nasiona konopi, jak i odpady pouprawowe. Skład nasion może ulegać zmianom w zależności od odmiany, roku zbiorów, warunków klimatycznych czy lokalnych czynników agronomicznych [23]. Staroindyjska literatura wymienia konopie jako lecznicze rośliny narkotyczne. Z łodyg osobników męskich konopi pozyskiwano miękkie, trwałe, zbliżone do lnianego włókno, z którego wyrabiano tkaniny. Włókno z osobników żeńskich, jako grube, trwałe, niegnijące w wodzie, służyło za surowiec do wyrobu lin, powrozów, sznurów, dratwy, sprzętu rybackiego i olinowania statków, a także tkanin namiotowych, pędzli, uprzęży i materiałów opatrunkowych. $\mathrm{Z}$ nasion pozyskiwano olej używany do oświetlenia, produkcji mydła, pokostu, farb i lakierów. Olej rafinowany używany był bezpośrednio do konsumpcji, a wytłoki jako pasza treściwa dla zwierząt gospodarskich [7, 12,44]. Uprawy konopi pozwalają na uzyskanie plonu słomy (suchej masy) w ilości ok. $10 \mathrm{t} \mathrm{z} 1$ ha, z której uzyskać można ok. 2,5 t wysokiej jakości, długowłóknistej masy celulozowej. Biorąc pod uwagę wzrost populacji i związany z tym wzrost zapotrzebowania na celulozę (prawdopodobnie dwukrotny w ciągu najbliższych 30 lat), można przewidywać, że w najbliższych latach stale utrzymywać się będzie trend zainteresowania konopiami, zwłaszcza z uwagi na konieczność ograniczania wycinki lasów [27]. Wzrasta też zainteresowanie konopiami wśród producentów kosmetyków, żywności oraz suplementów diety [8]. 


\section{Klasyfikacja konopi}

Konopie siewne (Cannabis sativa L.) to jednoroczne, dwupienne rośliny należące do rzędu różowców (Rosales) z rodziny konopiowatych (Cannabaceae) [21]. Wyróżnia się 3 podgatunki konopi: Cannabis sativa subsp. indica (Lam.) E. Small and A. Cronquist, Cannabis sativa subsp. sativa, Cannabis sativa var. ruderalis (Janisch.) S.Z. Liou.

Konopie należą do najwcześniej uprawianych gatunków roślin [32]. Odmiany botaniczne różnią się składem chemicznym, morfologią roślin, agronomią i przydatnością do przetwórstwa przemysłowego (konopie przemysłowe) oraz farmaceutycznego (konopie medyczne) [64]. Za zapach konopi odpowiedzialne są związki terpenowe. One też w charakterystyczny sposób przyczyniają się do wyjątkowych właściwości smakowych produktów z konopi $[5,39]$. Największa zawartość związków lotnych występuje $\mathrm{w}$ wiechach konopnych, a najmniejsza w łodygach, co jest zgodne $\mathrm{z}$ rozmieszczeniem gruczołów włoskowatych w roślinie. Głównymi węglowodorami seskwiterpenowymi są: $\beta$-kariofilen i $\alpha$-humulen, a monoterpenowymi - mircen oraz $\alpha$ - i $\beta$-pinen [5]. Terpeny zawarte $\mathrm{w}$ konopiach wykazują działanie przeciwbakteryjne, przeciwzapalne i uspokajające [51].

Podgatunki Cannabis sativa subsp. indica (zwane konopiami indyjskimi, marihuaną) oraz Cannabis sativa subsp. sativa (zwane też konopiami włóknistymi) znalazły wiele zastosowań w medycynie. Znaczenie konopi indyjskich w tym sektorze gwałtownie wzrosło, gdy tzw. medyczna marihuana została zalegalizowana w ponad połowie stanów USA oraz w Australii, Kanadzie, Niemczech, RPA czy Urugwaju. Zmiany legislacyjne utorowały drogę do rozwoju przemysłu konopnego, który jest jednym z najszybciej rozwijających się rynków na świecie [64].

Z powodu podobieństw pomiędzy konopiami włóknistymi a konopiami indyjskimi (o właściwościach narkotycznych) w większości krajów całkowicie zabroniono uprawy tych roślin. Jednak na przestrzeni ostatnich dwudziestu lat wiele krajów ponownie zalegalizowało uprawę konopi włóknistych, przyczyniając się do rozwoju badań nad ich właściwościami zdrowotnymi $[50,56]$. W Polsce uprawa tego rodzaju konopi jest dozwolona wyłącznie na potrzeby przemysłu włókienniczego, chemicznego, celulozowo-papierniczego, spożywczego, kosmetycznego, farmaceutycznego, materiałów budowlanych oraz nasiennictwa. Zakaz dotyczy uprawy i zbioru ziela lub żywicy konopi innych niż włókniste, przy czym wyjątek stanowią badania naukowe [61]. W Rejestrze Krajowym Centralnego Ośrodka Badania Odmian Roślin Uprawnych (COBORU) i we wspólnotowym Katalogu Odmian (CCA) znajduje się 7 odmian konopi włóknistych wyhodowanych w Instytucie Włókien Naturalnych i Roślin Zielarskich w Poznaniu o nazwach: Białobrzeskie, Beniko, Tygra, Wielkopolskie, Wojko, Rajan, Henola. Są to konopie krajowe, jednopienne, typowo włókniste, tzn. zawierające mniej niż $0,2 \%$ substancji psychoaktywnych w suchej masie ziela, o okresie wege- 
tacji dostosowanym do rodzimych warunków klimatyczno-glebowych [27]. Instytut Włókien Naturalnych i Roślin Zielarskich posiada kolekcję składającą się ze 150 genotypów, w tym jednopiennych i dwupiennych form konopi, pochodzących z różnych regionów świata, lokalnych ekotypów i linii hodowlanych o stabilnym genotypie, unikalnych pod względem plenności, zawartości psychoaktywnego kannabinoidu $\Delta$ 9-tetrahydrokannabinolu ( $\triangle 9$-THC lub THC), błonnika, a także kwasów tłuszczowych [36].

\section{Charakterystyka nasion}

Konopie przemysłowe są uprawiane głównie na nasiona, używane do produkcji oleju konopnego i włókien konopnych mających zastosowanie w przemyśle. Nasiona zawierają cenne składniki odżywcze. Są bogatym źródłem białka $(20 \div 25 \%)$, węglowodanów $(20 \div 30 \%$ ), na które składa się w większości błonnik (głównie nierozpuszczalny), tłuszczów $(25 \div 35 \%)$ o korzystnym profilu kwasów thuszczowych i pożądanym stosunku kwasów omega- 6 do omega-3 oraz innych biozwiązków $(10 \div 15 \%)[1$, $10,47,50,58]$. Nasiona konopi zawierają wiele makro- i mikroelementów, takich jak: fosfor $\left(11,2 \div 11,6 \mathrm{~g} \cdot \mathrm{kg}^{-1}\right)$, cynk $\left(42,0 \div 94,0 \mathrm{mg} \cdot \mathrm{kg}^{-1}\right)$, potas $\left(4,63 \div 28,2 \mathrm{~g} \cdot \mathrm{kg}^{-1}\right)$, ma-

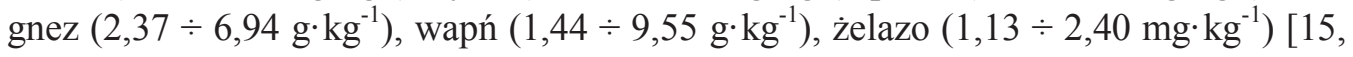
23, 30, 42, 64].

Białko w nasionach konopi zlokalizowane jest głównie w wewnętrznych jego częściach, co zostało stwierdzone na podstawie większej jego zawartości w nasionach łuskanych niż niełuskanych $[1,20,63]$. Podstawowym białkiem nasion konopi jest edestyna (klasyfikowana do legumin), która stanowi $67 \div 75 \%$ wszystkich białek zawartych $\mathrm{w}$ tych nasionach. W znacznych ilościach występują także albuminy $(25 \div$ $37 \%)[6,7,35]$. Białko nasion konopi zasługuje na uwagę, gdyż zawiera wszystkie niezbędne aminokwasy, w tym znaczne ilości argininy i kwasu glutaminowego oraz metioniny i cysteiny $[7,30]$. W porównaniu ze wzorcem zapotrzebowania na aminokwasy dla dzieci szkolnych zaproponowanym przez FAO/WHO (tzw. białko referencyjne) w nasionach w niedomiarze znajduje się lizyna, a także w mniejszym stopniu leucyna i tryptofan [20]. Białka nasion konopi są także wysokostrawne [7, 30]. Strawność białek determinowana jest przez ich strukturę, zawartość składników przeciwodżywczych oraz obróbkę wysokotemperaturową [20]. Białko niełuskanych nasion konopi charakteryzuje się strawnością na poziomie $85 \%$, natomiast łuskanych $-90,8 \div$ 97,5\%. Dla porównania strawność kazeiny wynosi 97,6 \%. Włókna zawarte w łusce są prawdopodobnie przyczyną zmniejszenia strawności białek [20].

Girgih i wsp. [17] wykazali, że peptydy nasion konopi uczestniczą we wzmocnieniu systemu ochronnego enzymów antyoksydacyjnych, neutralizowaniu rodników i hamowaniu peroksydacji lipidów. Dodatek hydrolizatu białka z nasion konopi włók- 
nistych do diety zwierząt może mieć działanie przeciwutleniające i potencjalnie terapeutyczne [64].

Do biozwiązków nasion konopi należą karotenoidy, związki fenolowe, tokoferole, fitosterole oraz peptydy [15, 23, 30, 42, 64]. Karotenoidy w nasionach konopi to przede wszystkim luteina oraz $\beta$-karoten i zeaksantyna w mniejszych ilościach [23]. Profil fenolowy tworzą głównie, zaliczane do lignanów, lignanoamidy i amidy fenolowe, a oprócz nich flawonoidy, takie jak: izoflawony, flawonole, flawanony, flawanole. Irakli i wsp. [23] stwierdzili, że dominującym amidem fenolowym jest N-transcaffeoiltyramina, natomiast kannabizyna A jest dominującym lignanoamidem (rys. 1). Worobiej i wsp. [63] dowiedli, że zawartość polifenoli była większa w nasionach niełuskanych niż w łuskanych, a najwięcej tych związków odnotowali w mące konopnej.

A

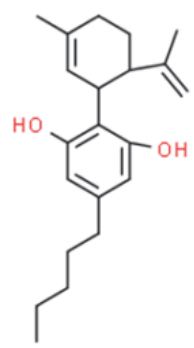

B

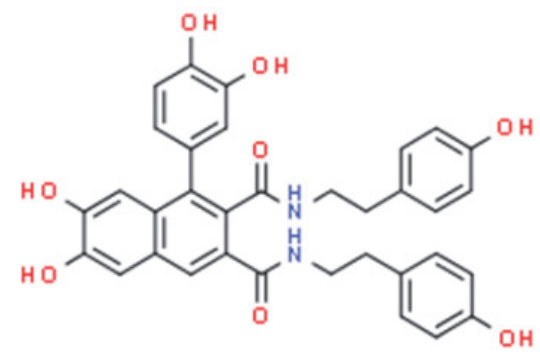

$\mathrm{C}$

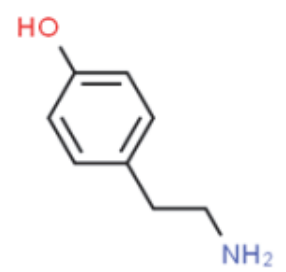

Objaśnienia / Explanatory notes:

A - kannabidiol (CBD) / cannabidiol (CBD), B - kannabizyna A / cannabisin A, C - caffeoiltyramina / caffeoyltyramine.

Rys. 1. Struktury chemiczne wybranych związków biologicznie czynnych konopi przemysłowych

Fig. 1. Chemical structures of selected biologically active compounds of industrial hemp

Źródło / Source: [51]

Niewiele publikacji naukowych poświęcono tematyce związków przeciwżywieniowych zawartych w nasionach konopi. Russo i Reggiani [52] wykazali obecność kwasu fitynowego, skondensowanych tanin, inhibitorów trypsyny, saponin i glikozydów cyjanogennych w mące pozyskanej przez mielenie i odtłuszczenie nasion sześciu odmian z terenów Włoch i Francji. Poziom glikozydów cyjanogennych w trzech z przebadanych odmian autorzy określili jako zbyt wysoki i szkodliwy dla zdrowia. Zawartość kwasu fitynowego wynosiła $6 \div 7 \%$, a np. soja zawiera $2 \%$ tego kwasu. Zawartość saponin obecnych $w$ nasionach scharakteryzowano jako mniejszą niż w nasionach soi [52]. Pojić i wsp. [45] w mące pozyskanej z mielenia odpadów po produkcji oleju konopnego zidentyfikowali inhibitory trypsyny, kwas fitynowy oraz skondensowane taniny, jednak ich ilość była mniejsza niż w próbkach, które przebadali Russo i Reggiani [52]. Jest to prawdopodobnie spowodowane tym, że próbki pochodzi- 
ły z różnych rejonów Europy [45]. Przeciwżywieniowe właściwości kwasu fitynowego wynikają z jego zdolności do zmniejszania biodostępności kationów magnezu i wapnia przez chelatowanie ich w kompleksy nierozpuszczalne w przewodzie pokarmowym. Kwas fitynowy może także doprowadzić do zmniejszenia strawności skrobi i białek poprzez hamowanie działania enzymów trawiennych, jak: pepsyna, trypsyna, $\beta$ glukozydaza i $\alpha$-amylaza. Glikozydy cyjanogenne stają się natomiast niebezpieczne, kiedy dojdzie do kontaktu ich cząsteczki z $\beta$-glukozydazą. Pod jej wpływem z cząsteczki uwalniany jest cyjanek, który doprowadza do zniszczeń i nekrozji tkanek przez uniemożliwienie wykorzystania tlenu obecnego we krwi [14].

\section{Olej z nasion konopi}

Nasiona konopi bogate są $\mathrm{w}$ thuszcze, a pozyskuje się je w postaci oleju. W aspekcie zastosowań przemysłowych tłuszcze stanowią najważniejszy składnik nasion [15]. Nierafinowany olej konopny ma ciemnozielone zabarwienie, które zawdzięcza obecności chlorofilu [35]. Zawartość oleju w nasionach, jego skład i jakość uzależnione są od czynników środowiskowych, takich jak: obszar uprawy, zabiegi agrotechniczne, odmiana, sposób przetwórstwa czy warunki przechowywania [29]. Kiralan i wsp. [29] wykazali, że zawartość tłuszczu w nasionach konopi pozyskanych z siedmiu prowincji w północno-zachodniej Turcji wahała się w zakresie 29,61 $\div$ $36,47 \%$, w zależności od rejonu upraw. Dwie próbki o największej zawartości tego składnika pochodziły z rejonów o umiarkowanym klimacie z zimną zimą i gorącym latem, natomiast próbka $\mathrm{z}$ najmniejszą zawartością pochodziła $\mathrm{z}$ rejonu wilgotnego $\mathrm{z}$ łagodnym klimatem [29]. W badaniach olejów konopnych dostępnych w Chorwacji stwierdzono, że zawartość kannabidiolu (CBD) wynosiła $4 \div 240 \mathrm{mg} \cdot \mathrm{kg}^{-1}, \Delta-9$ tetrahydrokannabinolu (THC) $-3 \div 69,5 \mathrm{mg} \cdot \mathrm{kg}^{-1}$, a kannabinolu $(\mathrm{CBN})-2 \div 8 \mathrm{mg} \cdot \mathrm{kg}^{-1}$ [44]. Świadczy to o dużej zmienności składu, chociaż wiele odmian przemysłowych jest źródłem oleju o wysokiej zawartości CBD [44].

Olej z nasion konopi charakteryzuje się bardzo korzystnym profilem kwasów tłuszczowych o małej zawartości nasyconych kwasów tłuszczowych (SFA) i dużej kwasów nienasyconych (PUFA) [29, 30]. Stosunek PUFA/SFA w produktach żywnościowych służy za wyznacznik ich wpływu na zdrowie układu sercowo-naczyniowego. Kwasy PUFA wpływają na zmniejszenie poziomu cholesterolu, natomiast SFA powodują jego zwiększenie, dlatego im wyższy jest ten indeks, tym jest to korzystniejsze [10]. Zawartość nasyconych kwasów tłuszczowych w nasionach konopi oceniana jest na ok. $10 \%$ [29]. Irakli i wsp. [23] zbadali siedem odmian przemysłowych nasion konopi i odnotowali, że głównym SFA był kwas palmitynowy $(7,1 \div 9,1 \%)$, następnie kwas stearynowy $(2,1 \div 2,8 \%)$, a w mniejszych ilościach występowały kwasy: arachidowy, behenowy i lignocenowy. Najważniejszym kwasem jednonienasyconym był kwas oleinowy $(10,3 \div 17,9 \%)$. Stwierdzono również obecność kwasu eikozenowego 
w małych ilościach. Wielonienasycone kwasy thuszczowe reprezentowane były przede wszystkim przez kwas linolowy $(51,6 \div 54,2 \%)$ oraz kwas $\alpha$-linolenowy $(10,5 \div$ $15,3 \%)$, a w mniejszych ilościach $-\gamma$-linolenowy $(1,9 \div 5,0 \%)$ [23]. Kiralan i wsp. [29] uzyskali podobne wyniki odnoszące się do olejów z nasion konopi z północnozachodniej Turcji. Kwas linolowy określili na poziomie $55,42 \div 56,94 \%$, $\alpha$-linolenowy $-16,51 \div 20,40 \%$. Potwierdzili obecność niewielkich ilości kwasów $\gamma$-linolenowego $(0,64 \div 1,10 \%)$ i stearydynowego $(0,34 \div 0,47 \%)$. Chen i Liu [10] oraz Kiralan i wsp. [29] podają, że zawartość kwasu $\gamma$-linolenowego jest większa w ziarnach pochodzących $\mathrm{z}$ upraw $\mathrm{z}$ rejonów o klimacie umiarkowanym i zimnym niż tych pochodzących z obszarów o klimacie łagodnym i ciepłym. Zdaniem wymienionych autorów zawartość kwasu oleinowego oscylowała w granicach $11,40 \div 15,88 \%$, a stosunek PUFA/SFA wynosił $8,6 \div 9,7$. Dla porównania PUFA/SFA oleju słonecznikowego mieści się w zakresie $4,75 \div 4,94$.

Inną zaletą oleju konopnego jest korzystny stosunek kwasów omega-6 (kwasu linolowego) do kwasów omega-3 (kwasu $\alpha$-linolenowego) $[13,16,29]$. Stosunek ten, szacowany na $3: 1$, może się zmieniać w zależności od szeregu czynników, w tym genotypu rośliny czy roku zbiorów [22, 41]. Irakli i wsp. [23] wykazali, że może wynosić 3,9 $\div 5,5$, natomiast Kiralan i wsp. [29] odnotowali 2,8 $\div 3,4$ i ich zdaniem jest on zależny od metody tłoczenia. $\mathrm{Z}$ tego względu zaleca się tłoczenie oleju na zimno w celu zachowania jego najkorzystniejszych proporcji $[23,29,55]$.

W oleju konopnym, w ilości mniejszej niż $2 \%$, występują frakcje niezmydlające zawierające tokoferole, fitol oraz w ok. $15 \%$ fitosterole [34]. Spośród tokoferoli wyróżnia się izomery $\gamma$ (w przewadze) oraz $\delta$, $\alpha$ i $\beta[3,62]$. Fitosterole reprezentowane są przez $\beta$-sitosterol. Związek ten wykazuje wysoką efektywność w hamowaniu wchłaniania cholesterolu, a co ważne, aktywność ta nie ulega zmniejszeniu nawet przy długotrwałym podawaniu związku. Brak toksyczności, niewielkie lub żadne skutki uboczne sprawiają, że $\beta$-sitosterol jest związkiem stosowanym w przypadku długotrwałej terapii zmniejszającej poziom cholesterolu [35].

Dzięki obecności kwasu $\gamma$-linolenowego (GLA) - do $4 \%$ - będącego cennym składnikiem nowoczesnych diet oraz znacznej ilości kwasu linolowego i $\alpha$ linolenowego, a także optymalnemu stosunkowi wielonienasyconych kwasów thuszczowych omega-6 do omega-3 olej konopny ma wielostronne zastosowanie jako środek spożywczy, farmaceutyczny i kosmetyczny, a także do produkcji tuszu do drukarek, środków do konserwacji drewna czy detergentów [27, 42]. Zabieg mikrofalowy zwiększa stężenie karotenoidów i innych barwników w oleju z nasion konopi, jednocześnie obniżając jego liczbę anizydynową. Olej z nasion konopi charakteryzuje się dużą stabilnością kinetyczną podczas grzania i chłodzenia [42]. 


\section{Fitochemia konopi}

Właściwości lecznicze konopi i pochodnych są szeroko rozpowszechnione i nadal wzbudzają wiele kontrowersji. W badaniach przedklinicznych wykazano, że marihuana lecznicza zapewnia korzyści zdrowotne, ma właściwości przeciwbólowe, łagodzi cierpienie pacjentów, którzy doświadczają przewlekłego bólu [40, 63]. W Cannabis sativa L. zidentyfikowano ponad 500 związków z różnych grup, jak: flawonoidy, dihydrostilbeny, fenantreny, spiroindany, ale najbardziej charakterystyczne dla tej rośliny są kannabinoidy $(\mathrm{CD})[16,33,54]$.

\section{Kannabinoidy}

Konopie zawierają ok. 60 kannabinoidów i ponad 140 terpenów [16, 33, 54]. Kannabinoidy, wydzielane przez gruczoły włośnikowe znajdujące się głównie na powierzchni liści, nazywane są egzokannabinoidami lub fitokannabinoidami. W latach 50. XIX w. wyizolowano z konopi pierwsze kannabinoidy - kannabinol (CBN) (budowa chemiczna została poznana dopiero w latach 30. ubiegłego wieku) i kannabidiol (CBD). W późniejszych latach zidentyfikowano m.in. $\Delta$ 9-tetrahydrokannabinol (THC), kannabigerol (CBG), kannabichromen $(\mathrm{CBC})$ oraz ich homologi: kannabidiwarin (CBDV), delta-9-tetrahydrokannabiwarin (THCV), kannabigerowarin (CBGV), kannabiwarichromen (CBCV) oraz formy kwasowe, np. kwas delta-9-tetrahydrokannabinolowy (THCA). Zawartość wymienionych związków w materiale roślinnym zależy od warunków agrotechnicznych, terminu i warunków zbioru oraz odmiany konopi $[26,53]$. W przeciwieństwie do konopi przemysłowych, konopie Cannabis sativa subsp. indica są uprawiane głównie dla pozyskania żeńskich kwiatów (pąków), które są bogate w kwas tetrahydrokannabinolowy (THCA, prekursor THC). Kwas ten jest również ekstrahowany z liści, chociaż zawartość THCA w liściach jest 10-krotnie mniejsza niż w kwiatach (o ok. $1 \div 2 \%$ ). W konopiach indyjskich stężenie THCA waha się w granicach $10 \div 30 \%$ i jest znacznie wyższe niż w konopiach przemysłowych. Konopie, których kwiaty i liście są używane w przemyśle farmaceutycznym zalicza się do upraw ogrodniczych. Rośliny te charakteryzują się dużą zawartością THCA i małą zawartością kwasu kanabidiolowego (CBDA). Konopie o małej zawartości THCA i dużej zawartości CBDA są uprawiane w celu pozyskania nasion. Konopie przemysłowe charakteryzują się małą (poniżej $1 \%$ ) zawartością THCA i stosunkiem CBD : THC wyższym niż 1 [64].

Konopie przemysłowe charakteryzują się stosunkowo wysokim poziomem kannabidiolu. Mieszanka CBD i THC może powodować korzyści zdrowotne, ponieważ kannabidiol (CBD) zmniejsza psychoaktywne skutki THC, jednak wysokie stężenia CBD nie są pożądane w produktach farmaceutycznych. Wyniki badań dotyczące poziomu CBD, stosunku CBD : THC i zdolności CBD do zmniejszania psychoaktywnych skutków THC są niejednoznaczne [64]. Appendino i wsp. [2] potwierdzili, że 
powyższe kannabinoidy są silnymi środkami przeciwdrobnoustrojowymi przeciwko różnym szczepom Staphylococcus aureus (MRSA) opornym na metycylinę. Podobne wyniki przedstawił Bancroft [4], który stwierdził, że niepsychotropowe kannabinoidy mogą być stosowane jako ogólnoustrojowe środki przeciwbakteryjne. Kombinacja kannabinoidów może być również używana jako surowiec do produkcji kosmetyków [33].

\section{Fitokannabinoidy w lecznictwie}

Do celów leczniczych wykorzystywane są naturalne fitokannabinoidy - THC i CBD. Sugeruje się, że kannabidiol może działać neuroprotekcyjnie poprzez ochronę osłonki mielinowej włókien nerwowych. Ponadto istnieją doniesienia o tym, że kannabidiol może działać przeciwzapalnie w różnych schorzeniach [54]:

- niedokrwiennej niewydolności wątroby, która może występować po przeszczepie, operacji na wątrobie oraz we wstrząsie,

- zapaleniu mózgu związanym z posocznicą, gdzie zaobserwowano efekt przeciwzapalny oraz stabilizacji naczyń krwionośnych,

- kardiomiopatii związanej z cukrzycą typu-1 oraz w cukrzycy typu-2,

- pneumokokowym zapaleniu opon mózgowych przez działanie przeciwzapalne i zmniejszanie niepożądanych zmian funkcji poznawczych,

- chorobie nowotworowej.

Według raportu Światowej Organizacji Zdrowia (WHO) czysty CBD jest dobrze tolerowany oraz charakteryzuje się odpowiednim profilem bezpieczeństwa. Skutki uboczne można przypisać interakcji między CBD a innymi lekami przyjmowanymi przez pacjenta. Kilka krajów zmieniło przepisy, aby umieścić CBD na liście produktów leczniczych [57].

Układ endokannabinoidowy składa się z receptorów (CB1 i CB2) w układzie nerwowym mięśni, kości, mózgu, w układzie odpornościowym, narządach wewnętrznych. Specyficzne receptory kannabinoidów różnią się powinowactwem do określonych substancji i lokalizacją (CB1 - dominują w ośrodkowym układzie nerwowym oraz zakończeniach nerwów obwodowych, CB2 - dominują w komórkach układu odpornościowego) $[16,31,39]$.

THC, poza działaniem psychoaktywnym, oddziałuje na kanały jonowe oraz enzymy. Efektem tego jest działanie przeciwbólowe, pobudzające, przeciwwymiotne, zwiększające apetyt, obniżające ciśnienie śródgałkowe. CBD nie wykazuje działania psychoaktywnego, lecz przeciwzapalne, przeciwbólowe, zapobiegające nudnościom, przeciwwymiotne, antypsychotyczne, zapobiegające niedokrwieniu, anksjolityczne oraz przeciwpadaczkowe. CBD prawdopodobnie nasila również działanie endokannabinoidów [39]. CBD wykazuje skuteczność w leczeniu niektórych chorób w połączeniu z THC. Mechanizm działania CBD nie został dostatecznie dobrze poznany. Skutki 
uboczne przyjmowania CBD obejmują nudności, zmęczenie i drażliwość. CBD może zwiększać stężenie niektórych leków we krwi poprzez taki sam mechanizm, jak ma miejsce w przypadku soku grejpfrutowego $[41,59,60]$. W wielu przypadkach samo określenie odpowiedniej dawki CBD stanowi wyzwanie. Preparaty lecznicze z konopi zazwyczaj są dobrze tolerowane, jednak istnieje szereg przeciwwskazań do ich stosowania, np. choroby psychiczne, leczenie środkami psychotropowymi, uzależnienia. Kryterium wyboru preparatu zawsze powinno stanowić dobro pacjenta, wynikające $z$ danych naukowych. $Z$ tych danych wynika, że CBD nie wykazuje działania uzależniającego i nie dowiedziono dotychczas, aby jego spożywanie (również w czystej postaci) wiązało się z istotnym ryzykiem dla zdrowia publicznego. W Unii Europejskiej żaden kraj, który zezwala na medyczne stosowanie preparatów konopnych, nie zaleca ich aplikowania drogą wziewną [39].

Kannabidiol (CBD) dostępny jest na rynku głównie jako ekstrakt z kwiatów lub liści konopi siewnych, jak również w formie rozpuszczonej w olejach jadalnych (tzw. olej CBD), np. słonecznikowym, konopnym tłoczonym na zimno czy oliwie z oliwek, [19]. CBD oferowany jest także w postaci izolatów oraz form syntetycznych [9]. Amerykańska Agencja ds. Żywności i Leków (U.S. Food and Drug Administration) zaaprobowała tylko jeden produkt na bazie oczyszczonego CBD pod nazwą Epidiolex. To lek doustny do stosowania w leczeniu napadów padaczkowych związanych z zespołem Lennoxa-Gastauta i zespołem Dravet [60].

Nowelizacją Ustawy o przeciwdziataniu narkomanii z 2017 r. dokonano zmiany klasyfikacji konopi innych niż włókniste na surowiec farmaceutyczny dozwolony do sporządzania leków recepturowych. Dotyczy to również ziela, wyciągów, nalewek farmaceutycznych [61].

\section{Kannabidiol jako sktadnik żywności}

Wytworzenie produktu zawierającego wyciąg z konopi z określoną zawartością CBD wymaga badań i wiedzy o surowcu. Jakość wyciągu z konopi zależy od odmiany rośliny, warunków uprawy, czasu zbioru oraz metod ekstrakcji. Wskazuje to na konieczność pełnej analizy składu celem zachowania standardów jakości produktu. Może to również przyczynić się do przedkładania stosowania izolatów oraz syntetycznego CBD nad ekstraktami [28].

Warunki ekstrakcji oraz użyte rozpuszczalniki mają znaczący wpływ na smak, barwę i lepkość uzyskanego produktu, ponieważ wiele innych substancji obecnych w materiale roślinnym ulega współekstrakcji. W celu poprawy parametrów ekstraktu poddaje się go często tzw. winteryzacji polegającej na wymrażaniu w temp. $-20 \div$ $-80{ }^{\circ} \mathrm{C}$ komponentów o wyższej temperaturze topnienia, takich jak woski czy triacyloglicerole. W tym procesie strąceniu ulega również chlorofil. Pozwala to następnie usunąć te związki z użyciem filtracji lub odwirowania [46]. Kannabinoidy z czasem ulega- 
ją chemicznej transformacji pod wpływem ogrzewania, utleniania oraz interakcji z innymi składnikami żywności, w tym z enzymami. Z tego powodu należy oszacować stopień degradacji składników aktywnych oraz przydatność do spożycia, aby zapewnić dokładne dawkowanie w produkcie spożywczym zanim zostanie on wprowadzony na rynek $[6,28]$.

Przygotowanie produktów spożywczych może stanowić wyzwanie technologiczne, ponieważ dostępne na rynku „oleje” z konopi są gorzkie w smaku oraz charakteryzują się dużą lepkością i smolistą konsystencją [28]. Oprócz podstawowego zastosowania nasion konopi w postaci oleju są one używane w formie zmielonej jako źródło białka roślinnego i błonnika pokarmowego w produktach spożywczych, takich jak: batony energetyczne, napoje mleczne, pieczywo i wyroby cukiernicze, sosy [1,50]. Mąka $\mathrm{z}$ nasion konopi stosowana $\mathrm{w}$ żywności funkcjonalnej pomaga w zapobieganiu niektórych chorób poprzez zwiększanie poziomu lipoprotein o wysokiej gęstości (HDL) i stabilizowanie poziomu innych acylogliceroli oraz lipoprotein [50]. Opracowano proces otrzymywania mleka konopnego, które nie zmieniało barwy i nie nabierało goryczy po poddaniu pasteryzacji. Ekstrakty z konopi dodawane są do takich produktów, jak: herbata, kawa, pizza, lizaki, płatki śniadaniowe, żelki, wyroby czekoladowe, suszona wołowina, a nawet piwo, wino, bezalkoholowe napoje na bazie jęczmienia, miód czy produkty dla sportowców. Chociaż najbardziej popularną częścią rośliny konopi są nasiona, to kiełki, liście i kwiaty mogą być również spożywane w postaci dodatku do soków lub sałatek [50].

Wątpliwości dotyczące produktów CBD związane są z zapewnieniem bezpieczeństwa i interesów konsumentów, które są priorytetem unijnego prawa. Do europejskiego systemu wczesnego ostrzegania o niebezpiecznej żywności i paszach (RASFF, ang. Rapid Alert System for Food and Feed) od lutego 2020 r. do stycznia 2021 r. wpłynęły 53 powiadomienia w sprawie obecności CBD jako nieautoryzowanej żywności [48]. W USA wykazano, że prawie $70 \%$ analizowanych produktów z rynku amerykańskiego było oznakowanych niezgodnie z przepisami (sugerowanie właściwości leczniczych), a stężenia składnika aktywnego były inne niż deklarowano na etykiecie. Niektóre produkty zawierały również THC, co stanowi naruszenie prawa konsumentów do bezpieczeństwa nabywanej żywności [39]. Na podstawie stanowiska Komisji Europejskiej Komisja Bezpieczeństwa Żywności i Żywienia Rady SanitarnoEpidemiologicznej przy Głównym Inspektorze Sanitarnym wyraziła 27.05.2019 r. opinię [22], że niektóre produkty pochodzące z Cannabis sativa L., takie jak: nasiona, olej z nasion, mąka z nasion konopi, odtłuszczone nasiona konopi, mające odnotowaną historię spożycia przed 15 maja 1997 r., nie powinny być traktowane jako tzw. nowa żywność. Wszelkie modyfikacje tradycyjnego procesu produkcji olejów konopnych, w tym programowana hodowla roślin, nowoczesne metody ekstrakcji, koncentracji, oczyszczania lub wzbogacania w celu podwyższenia zawartości CBD może skutkować 
tym, że produkt będzie postrzegany jako novel food. Wówczas jego obecność na rynku będzie nieuprawniona do czasu udzielenia przez Komisję Europejską zgody na wprowadzenie na rynek zgodnie z Rozporządzeniem 2015/2283 [49].

GIS stwierdza, że do czasu uzyskania autoryzacji obecność CBD w charakterze żywności na krajowym rynku jest nieuprawniona i niezbędne jest przeprowadzenie postępowania właściwego dla nowej żywności. Państwowa Inspekcja Sanitarna może poprosić przedsiębiorcę o przedłożenie dokumentacji, która potwierdzałaby historię spożycia takich produktów w UE przed 15 maja 1997 roku. Według GIS-u przedsiębiorca wprowadzający do sprzedaży jakiś środek, powinien dysponować danymi mówiącymi o jego bezpieczeństwie dla zdrowia i życia konsumentów. Polskimi placówkami naukowo-badawczymi, które mogą dokonać oceny nowej żywności są: Instytut Żywności i Żywienia, Narodowy Instytut Zdrowia Publicznego oraz Państwowy Instytut Weterynaryjny. Z uwagi na to, że niektóre produkty o dużym poziomie CBD zawierały psychoaktywny THC mogący powodować zatrucia, konieczne jest przeprowadzanie badań potwierdzających nieobecność tych substancji [22, 24, 49]. Znakowanie produktów otrzymywanych z konopi siewnych oraz informacje towarzyszące wprowadzaniu tych produktów do obrotu nie mogą wskazywać na działanie lecznicze, w tym na obecność związków o działaniu terapeutycznym, takich jak kannabidiol. W przypadku stwierdzenia $\mathrm{w}$ produktach konopi siewnych $\Delta$ 9-tetrahydrokannabinolu $(\Delta 9$ THC lub THC) konieczne jest każdorazowe dokonanie oceny ryzyka na podstawie przyjętej przez Europejski Urząd ds. Bezpieczeństwa Żywności ostrej dawki referencyjnej (ARfD) - $1 \mu \mathrm{g} \Delta 9$-THC/kg m.c. Za bezpieczeństwo środka spożywczego odpowiedzialność ponosi producent, zatem Komisja ds. Bezpieczeństwa Żywności i Żywienia zaleca, aby wymagania dotyczące zanieczyszczenia przez THC produktów otrzymanych na bazie konopi były wdrożone do systemu HACCP [43]. Stanowisko Komisji nie zwalnia producentów z obowiązku przestrzegania innych przepisów prawa w tym Ustawy z dnia 29 lipca 2005 r. o przeciwdziałaniu narkomanii [61].

\section{Literatura}

[1] Apostol L., Popa M., Mustatea G.: Cannabis sativa L. partially skimmed flour as source of biocompounds in the bakery industry. Rom. Biotechnol. Lett., 2015, 20 (5), 10835-10844.

[2] Appendino G., Gibbons S., Giana A., Pagani A., Grassi G., Stavri M., Smith E., Rahman M.: Antibacterial cannabinoids from Cannabis sativa: A structure - activity study. J. Nat. Prod., 2008, 71, 1427-1430.

[3] Bagci E., Brühl L., Aitzetmulle, K., Altan Y.: A chemotaxonomic approach to the fatty acid and tocochromanol content of Cannabis sativa L. (Cannabaceae). Tur. J. Bot., 2003, 27 (2), 141-147.

[4] Bancroft E.A.: Antimicrobial resistance: It's not just for hospitals. J. Am. Med. Assoc., 2007, 298 (15), 1803-1804.

[5] Booth J.K., Page J.E., Bohlmann J.: Terpene synthases from Cannabis sativa. PLoS ONE, 2017, 12 (3), \# $\#$ 0173911. 
[6] Brenneisen R.: Chemistry and analysis of phytocannabinoids and other cannabis constituents. In: Marijuana and the Cannabinoids. Ed. M.A. ElSohly. Humana Press Inc., Totowa 2007, pp. 17-49.

[7] Callaway J.C.: Hempseed as a nutritional resource: An overview. Euphytica, 2004, 140, 65-72.

[8] Cannabis infused edible products market-growth, trends, COVID-19 impact and forecasts (2021 2026). [on line]. Mordor Inteligence. Dostęp w Internecie [12.04.2021]: https://www.mordorintelligence.com/industry-reports/cannabis-infused-edible-products-market

[9] CBDepot files application on trans-Cannabidiol manufactured by chemical synthesis as a novel food. [on line]. CBDepot. Dostęp w Internecie [10.02.2021]: https://www.cbdepot.eu/pages/blog/cbdepotfiles-application-on-trans-cannabidiol-manufactured-by-chemical-syn

[10] Chen J., Liu H.: Nutritional indices for assessing fatty acids: A mini - review. Int. J. Mol. Sci., 2020, 21 (16), \#5695.

[11] Clarke R.A., Merlin M.D.: Cannabis: Evolution and ethnobotany. University of California Press, Berkeley 2013.

[12] Czikow P., Łaptiew J.: Rośliny lecznicze i bogate w witaminy. PWRiL, Warszawa 1987, ss. 169172.

[13] Dąbrowski G., Skrajda M.: Frakcja lipidowa i białkowa nasion konopi siewnych (C. sativa L.) oraz jej korzystny wpływ na zdrowie człowieka. Educat. Health Sport., 2016, 6 (9), 357-366.

[14] Dolan L.C., Matulka R.A., Burdock G.A.: Naturally occurring food toxins. Toxins, 2010, 2 (9), 2289-2332.

[15] Farinon B., Molinari R., Costantini L., Merendino N.: The seed of industrial hemp (Cannabis sativa L.): Nutritional quality and potential functionality for human health and nutrition. Nutrients, 2020, 12 (7), \#1935.

[16] Firenzuoli F., Epifani F., Loiacono I.: Konopie dla wszystkich. Lecznicze zastosowanie marihuany. Esteri, Wrocław 2016, ss. 17-23.

[17] Girgih A.T., Alashi A.M., He R., Malomo S.A., Raj P., Netticadan T., Aluko R.E.: A novel hemp seed meal protein hydrolysate reduces oxidative stress factors in spontaneously hyper tensive rats. Nutrients, 2014, 6 (12), 5652-5666.

[18] Here comes cannabis: How legalisation will disrupt global industries. [on line]. Euromonitor International. Dostęp w Internecie [12.04.2021]: https://go.euromonitor.com/white-paper-cannabis-2019here-comes-cannabis-how-legalisation-will-disrupt-global-industries.html

[19] Hazekamp A.: The trouble with CBD oil. Med. Cannabis Cannabinoids, 2018, 1, 65-72.

[20] House J.D., Neufeld J., Leson G.: Evaluating the quality of protein from hemp seed (Cannabis sativa L.) products through the use of the protein digestibility-corrected amino acid score method. J. Agric. Food Chem., 2010, 58 (22), 11801-11807.

[21] Integrated Taxonomic Information System [on-line]. Dostęp w Internecie [19-03-2021]: http://www.itis.gov

[22] Informacja Głównego Inspektora Sanitarnego w sprawie substancji kannabidiol (CBD). [on-line]. GIS 2018. Dostęp w Internecie [10.02.2021]: https://gis.gov.pl/wp-content/uploads/2018/ 12/Infornacja-w-sprawie-CBD.pdf

[23] Irakli M., Tsaliki E., Kalivas A., Kleisiaris F., Sarrou E., Cook C.: Effect of genotype and growing year on the nutritional, phytochemical, and antioxidant properties of industrial hemp (Cannabis sati$v a$ L.) seeds. Antioxidants, 2019, 8 (10), \#491.

[24] Jeżyk W.: CBD może niedługo zniknąć ze sklepów. [on-line]. Dostęp w Internecie [09.04.2021]: https://medycznamarihuana.com/cbd-moze-niedlugo-zniknac-ze-sklepow

[25] Johnson R.: Hemp as an agricultural commodity. [on-line]. Congressional Research Service 2018. Dostęp w Internecie [26.03.2021]: https://sgp.fas.org/crs/misc/RL32725.pdf

[26] Kaniewski R., Jankowiak J., Zajączek K.: Len i konopie w profilaktyce i lecznictwie. Postępy Fitoterapii, 2020, 21 (2), 100-103. 
[27] Kaniewski R., Pniewska I., Kubacki A., Strzelczyk M., Chudy M., Oleszak G.: Konopie siewne (Cannabis sativa L.) - wartościowa roślina użytkowa i lecznicza. Postępy Fitoterapii, 2017, 18 (2), 139-144.

[28] King J.W.: The relationship between cannabis/hemp use in foods and processing methodology. Current Opinion Food Sci., 2019, 28, 32-40.

[29] Kiralan M., Gul V., Kara S.: Fatty acid composition of hempseed oils from different locations in Turkey. Span. J. Agric. Res., 2010, 8 (2), 385-390.

[30] Kolodziejczyk P., Ozimek L., Kozłowska J.: The application of flax and hemp seeds in food, animal feed and cosmetics production. Handbook of natural fibres: Processing and Applications. Vol. 2. Woodhead Publishing, Duxford 2012, pp. 329-366.

[31] Komorowski J., Stępień H.: Rola układu endokannabinoidowego w regulacji czynności dokrewnej i kontroli równowagi energetycznej człowieka. Postepy Hig. Med. Dośw., 2007, 61, 99-105.

[32] Koren A., Sikora V., Kiprovski B., Brdar-Jokanovic M., Acimovic M., Konstantinovic B., Latkovic D.: Controversial taxonomy of hemp. Genetika, 2020, 52 (1), 1-13.

[33] Kurek-Górecka A., Balwierz R., Mizera P., Nowak M., Żurawska-Płaksej E.: Znaczenie terapeutyczne i kosmetyczne oleju konopnego. Farmacja Polska, 2018, 74 (12), 704-708.

[34] Leizer C., Ribnicky D., Poulev A., Dushenkov V., Raskin I.: The composition of hemp seed oil and its potential as an important source of nutrition. J. Nutraceut., Funct. Med. Foods, 2000, 2 (4), 35-53.

[35] Leonard W., Zhang P., Ying D., Fang Z.: Hempseed in food industry: Nutritional value, health benefits, and industrial applications. Compr. Rev. Food Sci. Food Saf., 2020, 19 (1), 282-308.

[36] Mańkowska G., Grabowska L.: Genetic resources of Cannabis sativa L. at the Institute of Natural Fibres and Medicinal Plants in Poznań. Herba Polonica, 2009, 55 (3), 178-184.

[37] Market overview. [on line]. Hempalta. Dostęp w Internecie [9.04.2021]: https://www.hempalta.com/market-overview/

[38] Mediavilla V., Steinemann S.: Essential oil of Cannabis sativa L. strains. J. Int. Hemp. Assoc., 1997, $4(2), 80-82$.

[39] Mirosz P.: Konopie i CBD: Superżywność czy lek? Korzyści, zagrożenia, status prawny w Unii Europejskiej. Współczesna Dietetyka, 2019, 23, 74-80.

[40] Murnion B.: Medicinal cannabis. Australian Prescriber, 2015, 38 (6), 212-215.

[41] National Center for Complementary and Integrative Health: Cannabis (Marijuana) and Cannabinoids: What You Need to Know. [on line]. Dostęp w Internecie [10.02.2021]: https://www.nccih.nih.gov/health/cannabis-marijuana-and-cannabinoids-what-you-need-to-know

[42] Oomah B.D., Busson M., Godfrey D.V., Drover J.C.G.: Characteristics of hemp (Cannabis sativa L.) seed oil. Food Chem., 2002, 76, 33-43.

[43] Opinia Komisji ds. Bezpieczeństwa Żywności i Żywienia z dnia 27.05.2019 r. w sprawie bezpieczeństwa stosowania konopi siewnych w żywności ze względu na obecność THC i CBD. [on line]. Dostęp w Internecie [14.04.2021]: https://gis.gov.pl/wp-content/uploads/2019/07/Opinia-KomisjiB\%c5\%bb\%c5\%bb-RSE-Konopie.pdf

[44] Petrowić M., Debeljak Ž., Kezić N., Džidara P.: Relationship between cannabinoids content and composition of fatty acids in hempseed oils. Food Chem., 2015, 170, 218-225.

[45] Pojić M., Misan A., Sakac M., Dapcević Hadnadev T., Sarić B., Milovanović I., Hadnadev M.: Characterization of by-products originating from hemp oil processing. J. Agric. Food Chem., 2014, 62 (51), 12436-12442.

[46] Puri P.S.: Winterization of oils and fats. J. Am. Oil Chem. Soc., 1980, 57, A848-A850.

[47] Ranalli P., Venturi G.: Hemp as a raw material for industrial applications. Euphytica, 2004, 140, 1-6.

[48] RASFF Portal. [on line]. Dostęp w Internecie [10.02.2021]: https://webgate.ec.europa.eu/rasffwindow/portal/?event=SearchForm\&cleanSearch $=1$ 
[49] Rozporządzenie Parlamentu Europejskiego i Rady (UE) 2015/2283 z dnia 25 listopada 2015 r. w sprawie nowej żywności, zmieniające rozporządzenie Parlamentu Europejskiego i Rady (UE) nr 1169/2011 oraz uchylające rozporządzenie (WE) nr 258/97 Parlamentu Europejskiego i Rady oraz Rozporządzenie Komisji (WE) nr 1852/2001. Dz. U. L 327, ss. 1-22, z 11.12.2015.

[50] Rupasinghe H.P.V., Davis A., Kumar S.K., Murray B., Zheljazkov V.D.: Industrial hemp (Cannabis sativa subsp. sativa) as an emerging source for value-added functional food ingredients and nutraceuticals. Molecules, 2020, 25 (18), \#4078.

[51] Russo E.B.: Taming THC: Potential cannabis synergy and phytocannabinoid-terpenoid entourage effects. Brit. J. Pharmacol., 2011, 163, 1344-1364.

[52] Russo R., Reggiani R.: Variability in antinutritional compounds in hempseed meal of Italian and French varieties. Plant, 2013, 1 (2), 25-29.

[53] Rymanowski M.: Konopie, przegląd zagadnień związanych z oznaczaniem sumarycznej zawartości delta-9-tetrahydrokannabinolu (D-9-THC) oraz kwasu delta-9-tetrahydrokannabinolowego (D-9THCA-A). Probl. Kryminalist., 2014, 258 (3), 2-23.

[54] Siudem P., Wawer I., Paradowska K.: Konopie i kannabinoidy. FarmacjaWspółczesna, 2015, 8, 1-8.

[55] Spano M., Di Matteo G., Rapa M., Ciano S., Ingallina C., Cesa S., Menghini L., Carradori S., Giusti A.M., Di Sotto A., Di Giacomo S., Sobolev A.P., Vinci G., Mannina L.: Commercial hemp seed oils: A multimethodological characterization. Applied Sciences, 2020, 10 (19), \#6933.

[56] Struik P.C., Amaducci S., Bullard M.J., Stutterheim N.C., Venturi G., Cromack H.T.H.: Agronomy of fibre hemp (Cannabis sativa L.) in Europe. Industr. Crops Products, 2000, 11, 107-111.

[57] World Health Organization, Expert Committee on Drug Dependence: Cannabidiol (CBD) Critical Review Report. [on line]. WHO, Geneva 2018. Dostęp w Internecie [10.02.2021]: https://www.who.int/medicines/access/controlled-substances/CannabidiolCriticalReview.pdf

[58] Taura F., Sirikantaramas S., Shoyama Y., Yoshikai K., Shoyama Y., Morimoto S.: Cannabidiolicacid synthase, the chemotype-determining enzyme in the fiber-type Cannabis sativa. FEBS Letters, 2007, 581 (16), 2929-2934.

[59] U.S. Food and Drug Administration: What you need to know (and what we're working to find out) about products containing cannabis or cannabis-derived compounds, including CBD. [on line]. FDA. Dostęp w Internecie [10.02.2021]: https://www.fda.gov/consumers/consumer-updates/what-youneed-know-and-what-were-working-find-out-about-products-containing-cannabis-or-cannabis

[60] U.S. Food and Drug Administration: FDA approves first drug comprised of an active ingredient derived from marijuana to treat rare, severe forms of epilepsy. [on line]. FDA 2018. Dostęp w Internecie [10.02.2021]: https://www.fda.gov/news-events/press-announcements/fda-approves-first-drugcomprised-active-ingredient-derived-marijuana-treat-rare-severe-forms

[61] Ustawa z dnia 29 lipca 2005 r. o przeciwdziałaniu narkomanii. Dz.U. 2005 r. Nr 179, poz. 1485.

[62] Vonapartis E., Aubin M.-P., Seguin P., Mustafa A., Charron J.-B.: Seed composition of ten industrial hemp cultivars approved for production in Canada. J. Food Compos. Anal., 2015, 39, 8-12.

[63] Worobiej E., Mądrzak J., Piecyk M.: Zawartość wybranych składników odżywczych i związków biologicznie aktywnych w produktach z konopi siewnych (Cannabis sativa L.) oraz kasztanów jadalnych (Castanea sativa Mill.). Bromat. Chem. Toksykol., 2015, 48 (3), 573-577.

[64] Żuk-Gołaszewska K., Gołaszewski J.: Cannabis sativa L. - cultivation and quality of raw material. J. Elem., 2018, 23 (3), 971-984. 


\section{HEMP CANNABIS SATIVA L. - TYPES, PROPERTIES, USES}

\section{$\mathrm{S} \mathrm{u} \mathrm{m} \mathrm{m} \mathrm{a} \mathrm{r} \mathrm{y}$}

Hemp (Cannabis sativa L.) is an ancient cultivated plant originating from Central Asia with a wide range of applications. The article presents a review of the literature on hemp, its active compounds, biological activity, medicinal properties and potential use in medicine and food. Hemp seeds are widely used in food industry as they are a good source of protein, fibre, vitamin E, iron, calcium, zinc, phosphorus and magnesium. Terpene hydrocarbons account for the taste and smell of hemp, mainly $\beta$-caryophyllene and $\alpha$-humulene (sesquiterpenes) and monoterpene, myrcene. Currently the main focus of the industry is the seed-pressed oil rich in tocopherols, phytosterols, carotenoids, polyphenols and phospholipids. Hemp oil contains over $80 \%$ of EFAs, including $\gamma$-linolenic (GLA), linoleic and $\alpha$-linolenic acids, with an optimal $3: 1$ ratio of omega- 6 to omega-3 polyunsaturated fatty acids. The use of oil in the food technology is limited owing to its intense colour and taste. Other active compounds identified in Cannabis sativa L. are cannabinoids, dihydrostilbenes and spiroindanes. Cannabinoids are characterised by anti-inflammatory, antibacterial, analgesic and antidepressant properties. Hemp seed products are additives for tea, coffee, chocolate products, milk drinks, bakery and confectionery products and also beer, wine, honey or products for sportsmen. In the article there are also discussed legal requirements referring to possible uses of cannabinoids in food and introduction of food products containing cannabinoids to the market.

Key words: hemp, cannabinoids, THC, CBD, food and medicinal use 